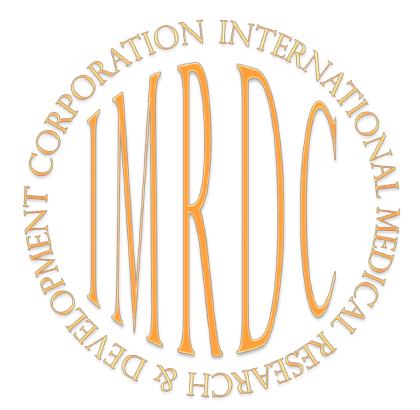

\title{
The Role of Integrated Gas Compounds in Regulation of Gas Homeostasis in the Norm
}

\author{
Alexander G. Kruglov, PhD, ScD*; Valery N. Utkin; Alexander Yu. Vasilyev, PhD, ScD \\ Central Research Institute of Radiation Diagnosis \\ Moscow, the Russian Federation
}

\begin{abstract}
In practically healthy people on the background of self-breathing, we used catheterization to obtain blood samples from Ao, PT, SC, VJI, SS, VH and VR. We believe that the standard tests of blood gases by volume $\left(\mathrm{pO}_{2}\right.$ and $\left.\mathrm{pCO}_{2}\right)$ and their A-V gradients, quantitatively determined, are insufficient to fully assess the hypoxic states both in the whole organism and in individual organs. To estimate gas homeokinesis, we performed integral gas tests, including an additive criterion of blood gases - pressure in mmHg: 1) the summary pressure of the plasma gases, PS; 2) Gas functional, the gradient between the total indices of arterial and vein gases (Gradient D); and 3) the exchange gradient, Gradient $\mathrm{DP}\left[\left(\operatorname{arterial} \mathrm{pO}_{2}-\right.\right.$ venous $\left.\left(\mathrm{pO}_{2}+\mathrm{pCO}_{2}\right)\right]$. Each test indicator at all studied points was determined in $\mathrm{mmHg}$. Correlation analyses were carried out between the parameters of all tests.

We found that the processes forming PS limit the amplitude of the PS deviation under changing parameters of the constituent components $\left(\mathrm{pO}_{2}\right.$ and $\left.\mathrm{pCO}_{2}\right)$ due to acts of mutual replacement between them, as well as the influence of integral gas complexes under shifts in $\mathrm{pO}_{2}, \mathrm{pCO}_{2}, \mathrm{~A}-\mathrm{V} \mathrm{SO}$. Unlike the generally accepted tests that record quantitative differences between the points studied, the integral gas tests allow us to identify vectors and mechanisms of adaptive changes in gas homeostasis, to perform a qualitative comparison of the functioning of the studied organs by gas-dynamic tests in the norm and in pathology.(International Journal of Biomedicine. 2017;7(3):185-191.)
\end{abstract}

Key Words: integrated gas compounds • blood gases • gas homeokinesis • gas functional

\section{Abbreviations}

Ao, aorta; A-V, arteriovenous; BP, blood pressure; DP, diastolic pressure; Er, erythrocyte; MP, mean pressure; PT, pulmonary trunk; PI, plasma; PP, pulse pressure; PS, summary gas pressure; P-n, total protein; PSv - PS of venous blood; RV, right ventricle; SS, sigmoid sinus; $\mathbf{S P}$, systolic pressure; $\mathbf{S C}$, coronary sinus; $\mathbf{S O}_{2}$, oxygen saturation; VJI, internal jugular vein; VH, right hepatic vein; $\mathbf{V R}$, right renal vein.

The aim of the study was to evaluate the distribution of the PS values in the investigated points of the human body and their participation in the regulation of gas homeostasis in the norm.

\section{Methods and Results}

With the patient in the supine position, we used catheterization to obtain blood samples from the outflow vessels of the three-chamber block of ventricles (Ao, PT, $\mathrm{SC})$, VJI, VH, and VR. ${ }^{(1)}$ To investigate general and organ gas exchange, in normal practice, we used data for temporal

*Corresponding author: Alexander G. Kruglov, PhD, ScD. Central Research Institute of Radiation Diagnosis. Moscow, the Russian Federation.E-mail: krag48@mail.ru dynamics arterial and venous blood and their $\mathrm{A}-\mathrm{V}$ gradients. In our opinion, the separately taken values of $\mathrm{pO}_{2}$ and $\mathrm{pCO}_{2}$ are changed quantitatively (in absolute values) and are inadequate for evaluating polyorganic hypoxic states, since the use of the general average values does not reveal qualitative changes that characterize and explain the so-called mutual replacements of $\mathrm{PO}_{2}$ and $\mathrm{pCO}_{2}$ at varying ratios of the levels of $\mathrm{pO}_{2}$ and $\mathrm{pCO}_{2}$ (the biophysical equivalent of the Haldane effect) in the investigated areas of the human body.

To estimate the gas homeostasis, along with the generally accepted methods we used tests that take into account the additive trait for $\mathrm{pO}_{2}$ and $\mathrm{pCO}_{2}-$ a pressure in $\mathrm{mmHg}$ :

1) $\mathrm{PS}=\mathrm{pO}_{2}+\mathrm{pCO}_{2}$ (at each investigated point)

2) Gas functional (Gradient D, GD) between PSs in arteries and veins $\left(\mathrm{GD}=\left(\mathrm{pO}_{2}+\mathrm{pCO}_{2}\right) \mathrm{A}-\left(\mathrm{pO}_{2}+\mathrm{pCO}_{2}\right) \mathrm{V}\right)$.

3) Exchange gradient (Gradient DP, GDP) [(arterial $\mathrm{pO}_{2}-$ 
venous $\left.\left(\mathrm{pO}_{2}+\mathrm{pCO}_{2}\right)\right]$. GDP between $\mathrm{Ao}_{2} \mathrm{O}_{2}$ (which provides metabolic processes involving $\mathrm{O}_{2}$, including the binding of $\mathrm{O}_{2}$ to $\mathrm{Hb}$ ), and PSv (which is formed as a result of metabolism, including $\mathrm{Hb}-\mathrm{O}_{2}$ dissociation) that change conjugately and unidirectionaly $(+)$.

These tests can be changed quantitatively (absolute values) and qualitatively (by sign). Unlike gas volume tests, gradient DP is less dependent on the factors affecting $\mathrm{O}_{2}$ transport in the vascular bed, $\mathrm{Hb}$ concentration, or stroke and minute heart volumes. GDP helps to identify the qualitative differences in organ metabolism that are not determined by other methods. The complementary relationship between two test groups makes possible their joint application.

The following values and correlations between the proposed tests were calculated for Ao-TP (heart-lung block); $\mathrm{A}_{\mathrm{o}}$-CS (myocardium block); Ao-VJI (brain block); Ao-VH (liver block); and Ao-VR (kidney block). As a result, we obtained information on the distribution of integrated gas indicators at various points of the human cardiovascular system. $^{(2-5)}$ The vector and amplitude of the distribution of the indices studied were determined by the relationships with the mean hemodynamic pressure of each organ (Pmed, defined as the initial value of the perfusion pressure, which provides the metabolism). We present cases with the following parameters: $\mathrm{Ao}_{\mathrm{pCO}}-30-45 \mathrm{mmHg}$, $\mathrm{Ao} \mathrm{PO}_{2}-70-100 \mathrm{mmHg}$, $\mathrm{HR}-75.6 \pm 1.2 \mathrm{bpm}, \mathrm{Hb}-13.1 \pm 1.4 \mathrm{~g} / \mathrm{l}, \mathrm{Ht}-45.0 \pm 0.1 \%$. The remaining data are presented in Table 2.

The quantitative, numerical results of gas homeostasis, which we have studied for a long time, were presented earlier in our works. ${ }^{(6-34)}$ The results of the study of the qualitative relationships of the gas homeostasis in the norm are given in Table 1 , which shows statistically significant $(\mathrm{P}<0.05)$ values $(+, 0,-)$ of correlations for the studied parameters, without indicating their magnitudes.

It should be noted that the correlation analysis showed the absence of reliable links for all proposed tests with $\mathrm{Hb}$ in all investigated points (in contrast to volume-additive tests), gas functionals with $\mathrm{pCO}_{2}$ and $\mathrm{pO}_{2}$ at all the points studied, and Ao PS with $\mathrm{pCO}_{2}$ at all points.

Reliable correlations for PS levels in venous points with $\mathrm{pO}_{2}$ (positive) and $\mathrm{pCO}_{2}$ (positive) in Ao blood were revealed, which indicates a combined unidirectional dynamics of these processes. We believe that this is why PSv can remain constant at a significant amplitude of shifts in $\mathrm{pO}_{2}, \mathrm{pCO}_{2}$ and $\mathrm{HbO}_{2}(\%)$, due to acts of mutual replacement of $\mathrm{pO}_{2}$ and $\mathrm{pCO}_{2}$. Reflection of the general dependence on $\mathrm{Ao}_{\mathrm{pO}}$ is positively correlated with PS levels at the venous points. We believe that this is a reason for the stability of PSv with significant shifts in the parameters of blood gases and $\mathrm{HbO}_{2}$. Thus, $\mathrm{SC}$ PS is positively correlated with $\mathrm{VR} \mathrm{pO}_{2}$, and gradient $\mathrm{DP}$ is positively correlated with $\mathrm{Ao} \mathrm{pO}_{2}$.

We estimated the distribution of PS in the outflow vessels of the three-chambered block of heart ventricles (Ao, TP, SC), including studying the reproducibility of this distribution in different states of the human body. According to data of the norm in the blood of Ao, TR, SC, VJI, VH, VR, we determined $\mathrm{pO}_{2}, \mathrm{pCO}_{2}$ in $\mathrm{mmHg}$, their $\mathrm{A}-\mathrm{V}$ gradients, $\mathrm{PS}$, as well as special gradients: GD and GDP.
Thus, the following correlations between the proposed tests were calculated: Ao-TP (heart-lung block); AO - CS (myocardium block); Ao-VJI (brain block); Ao-VH (liver block), and Ao-VR (kidney block).

To determine the vector and amplitude of the distribution of the investigated indices, their relationships with Pmed were analyzed in the investigated areas. [bulbus Ao $(86.5 \pm 1.7)$, SC (5.3 \pm 0.4$)$, TP (14.0 \pm 0.22$)$, SS (9.4 \pm 1.2$)$, VJI $(6.7 \pm 1.3)$, RA (4.1 \pm 0.72$)$, LA (8.1 \pm 0.8$)$; HR (75.6 $\pm 1.2 \mathrm{bpm}), \mathrm{Hb}(13.1 \pm 1.4$ $\mathrm{g} / \mathrm{l}), \mathrm{Ht}(45.0 \pm 0.1 \%)]$.

All data were obtained under self-breathing. The data presented were investigated in the same order as blood ejection from the three-chamber block of ventricles into the outflow vessels (Ao, TP, SC) during united systole. ${ }^{(14)}$

When analyzing the baseline data, we established the stable changes in PS, regardless of the sampling point of blood, conjugate to changes and equivalent to the magnitude of the changes of each gas by its total value (both an increase and a decrease). It is also noted that PS can vary in the following directions: 1) less than one of them, but more than the other; and 2) less than the value of each of them, minimizing PS deviations and compensating the shifts of individual parameters.

PS is greater in those areas where Pmed is also greater (Table 2): the maximum in $\mathrm{Ao}$ (for $\mathrm{pO}_{2}>\mathrm{pCO}_{2}$ ); the minimum in $\mathrm{SC}$ (for $\mathrm{pO}_{2}<\mathrm{pCO}_{2}$ ); intermediate in $\mathrm{TP}\left(\mathrm{pO}_{2}=\mathrm{pCO}_{2}\right.$ ). PS values in the outflow vessels are close, or correspond, to the values of systemic $\mathrm{BP}$ :

- Ao PS (for $\mathrm{pO}_{2}>\mathrm{pCO}_{2}$ ) is within SBP: maximum $=145$ $\mathrm{mmHg}\left[\mathrm{pO}_{2}(100 \mathrm{mmHg})+\mathrm{pCO}_{2}(45 \mathrm{mmHg}) ;\right.$ minimum $=100$ $\mathrm{mmHg}\left[\mathrm{pO}_{2}(70 \mathrm{mmHg})+\mathrm{pCO}_{2}(30 \mathrm{mmHg})\right]$.

- TP PS (with variable ratios of $\mathrm{pO}_{2}$ and $\mathrm{pCO}_{2}$ ) is mathematically close to the average BP in the norm ( $\mathrm{PS}=$ $84.8 \pm 0.5 \mathrm{mmHg}, \mathrm{BP}=86.5 \pm 5.1 \mathrm{mmHg}$.)

- PS SC (for $\mathrm{pO}_{2}<\mathrm{pCO}_{2}$ ) is mathematically close (within the statistical error) to $\mathrm{DBP}(\mathrm{PS}=71.3 \pm 0.6 \mathrm{mmHg}, \mathrm{DBP}=71 \pm 0.38 \mathrm{mmHg}$ )

The values of these parameters are formed in the chambers of the three-chambered block of ventricles at the end-diastolic pressure in the right and left ventricles and the average pressure in SC. All pressure values (PS and systemic BP) are created conjugately between each other and other parameters of the cardiocycle on a single basis (the impulse of a quantum generator): contraction of the myocardium of the three-chambered block of ventricles.

The data presented demonstrate the dynamics of the regulation of gas homeostasis in the norm in the investigated areas of the body:

\section{$\underline{\mathrm{SC}}$}

A) Levels of $\mathrm{pO}_{2}$ and PS are minimal in comparison with other investigated points.

B) Gradients with respect to $\mathrm{pO}_{2}, \mathrm{pCO}_{2}$, and gas functionals are maximal in comparison with the other investigated points.

C) SC PS is less than arterial blood $\mathrm{pO}_{2}$, and gradient $\mathrm{DP}$ for the heart is positive $(20.66 \pm 0.44 \mathrm{~mm} . \mathrm{Hg}){ }^{(2,10,36,37)} \mathrm{PS}$ of SC blood, outflowing from the spongy (venous) chamber of threechambered block of ventricles, is minimal $(71.0 \pm 0.6 \mathrm{mmHg})$ and close to the systolic pressure in the aorto-pulmonary block with placental and beginning pulmonary gas exchange (open 
Botalli's duct), when it functions as a single chamber. ${ }^{(16)}$

$\mathrm{SC} \mathrm{PO}_{2}$ corresponds to the values of the hypoxic limit found in the venous blood of other points: VJI of $20 \mathrm{mmHg}$ is a critical level, accompanied by loss of consciousness. Figuratively speaking, the blood flow from the spongy (venous) chamber of three-chambered block of ventricles includes the criteria of the hypoxic limit of the human body. ${ }^{(27)}$

TP:

PS in mixed venous blood, the flow of which is created at different ratios of $\mathrm{pO}_{2}$ and $\mathrm{pCO}_{2}$ flowing from $\mathrm{RV}(84.8 \pm 5.0$ $\mathrm{mmHg}$ ), is lower than in Ao blood and close to arterial blood $\mathrm{pO}_{2}$ (91.7 $\pm 0.5 \mathrm{mmHg}$ ) and to Pmed in Ao bulbus ( $86.5 \pm 1.7 \mathrm{mmHg}$ ).

This venous flow is created by the mixing of blood flowing from the spongy chamber of three-chambered block of ventricles, mixing with the flow of venous blood from the lower and upper hollow veins. A measure of the adequacy of the combined and unidirectional shifts of TP PS and Ao $\mathrm{pO}_{2}$ is Gradient DP (91.91 $\pm 0.5 \mathrm{~mm} . \mathrm{Hg})$, varying both in magnitude and in sign $(+, 0,-)$ within the values obtained for the kidneys and the heart. ${ }^{(11,15,16)}$ TP PS is mathematically close (within the margin of error) to PS in VJI and $\mathrm{VH}$, with a common proximity to Ao Pmed.

Ao:

PS of the blood flowing from VS, at $\mathrm{pO}_{2}$ greater than $\mathrm{pCO}_{2}$, is maximal $(128.3 \pm 0.6 \mathrm{mmHg})$ and close to SBP in aortic bulb $(107.6 \pm 2.6 \mathrm{mmHg})$; it is created by the mixing of the blood of RV and Thebesian veins of LA and LV, having ability to direct and reverse the flow of blood (twoway communications of the left heart chambers with the myocardium by pressure).

VJI:

PS $(84.89 \pm 0.54 \mathrm{mmHg})$ is mathematically (within the margin of error) close to the following parameters of arterial and venous blood:

a) Average Ao pO2 (85.72 $\pm 0.65 \mathrm{mmHg})$; the measure of adequacy of unidirectional shifts of Ao pO2 and VJI PS is Gradient DP $(0.83 \pm 0.57 \mathrm{mmHg})$;

b) Average Ao Pmed ( $86.5 \pm 1.7 \mathrm{mmHg})$;

c) TS PS $(84.8 \pm 0.5 \mathrm{mmHg})$.

It should be noted that the blood of VJI is formed by mixing the venous streams of two zones:

1) Tissue zone (removal of brain metabolites) with low $\mathrm{pO}_{2}$

2) Cerebrospinal fluid (choroidal plexus) with high $\mathrm{pO}_{2}$

We consider a significant fact to be almost complete coincidence (within the margin of error) of quantitative indicators of $\mathrm{pCO}_{2}$ levels in the blood of VJI and $\mathrm{SC}$, while noting the difference in $\mathrm{pO}_{2}$ levels. We assume that the minimum value of $\mathrm{pO}_{2}(23.77 \pm 0.3 \mathrm{mmHg})$ among the recorded values during catheterization is the individual hypoxic limit of the organism.

VH:

PS $(88.51 \pm 0.54 \mathrm{mmHg})$ is mathematically close to IVC PS, Ao Pmed, and Ao $\mathrm{pO}_{2}{ }^{(20.29 .35)} \mathrm{A}$ measure of the adequacy of the unidirectional shifts of $\mathrm{Ao}_{\mathrm{pO}}$ and $\mathrm{VH}$ PS is Gradient DP $(1.93 \pm 0.54 \mathrm{mmHg})$. VH Pmed is mathematically close to the pressure in the liver parenchyma $(8.0 \pm 0.7 \mathrm{mmHg})$ and $\mathrm{PV}$ $(8.42 \pm 0.76 \mathrm{mmHg})$ with a minimum of gradients between these three points.
VR:

Under superperfusion and the mixing of the blood inside the kidney (A-V shunts), including juxtaglomerular blood fractions with differences in $\mathrm{pO}_{2}$ and $\mathrm{pCO}_{2}$ in countercurrent exchange (analogue of the mixing process), there are formed 1) the maximal $\mathrm{pO}_{2}$ and VR PS levels in comparison with those for brain block, heart-lungs block, myocardium block, and liver block, wherein the ratio $\mathrm{VR} \mathrm{pO}_{2}>\mathrm{VR} \mathrm{pCO}_{2}$ is similar to that in Ao blood; 2) the values of Gradient $\mathrm{D}$ for $\mathrm{pO}_{2}, \mathrm{SO}_{2}$ and $\mathrm{PS}$ for the studied organs and blocks (heart-lungs, splanchnic pool, brain) are minimal; 3) VR PS is greater than $\mathrm{Ao}_{\mathrm{pO}}$, therefore, Gradient DP for the kidneys is negative $(-11.9 \pm 0.57) .^{(20,25,27,28,31,32)}$ We believe that the upper limit of the norm for oxygenation $\left(\mathrm{pO}_{2}\right)$ of venous blood is $\mathrm{VR}_{2}$. In the blood of TP, VJI and VH, the blood oxygenation levels can vary between the minimum limit $\left(\mathrm{SC} \mathrm{pO}_{2}\right)$ and the maximum limit $\left(\mathrm{VR} \mathrm{pO}_{2}\right)$. The values of gas parameters beyond the maximum and minimum values can be a sign of decompensation of gas homeostasis.

A detailed analysis of all the qualitative and quantitative indicators (Table 1 and 2) was presented by us in earlier works. $(15,16,17-24,34)$

The interaction of specific proteins with different affinities for $\mathrm{O}_{2}$ is a unifying factor in the gas exchange of the heart, brain and kidneys.

1) In the heart, myoglobin $(\mathrm{Mb})$ has an affinity to $\mathrm{O}_{2}$ 6 times greater than $\mathrm{Hb}$, with a shorter dissociation time and association of $\mathrm{Mb}$ and $\mathrm{O}_{2}$, with the possibility of forced dissociation of $\mathrm{HbO}_{2}$ at $\mathrm{SO}_{2}$ of $50 \%$ and lower.

2) In adults, the mixing of blood flows with differences in $\mathrm{pO}_{2}$ and $\mathrm{SO}_{2}$ is a common characteristic in the formation of the blood composition in VJI and VR, as in the fetus - the mixing of blood of v.umbilicalis with its own venous blood (intravascular gas exchange).

The dissociation and association of $\mathrm{HbO}_{2}$ in different sections of the $\mathrm{S}$-shaped curve depends on temperature, $\mathrm{pH}$, electrolytes, etc. in different ways, as well as the $\mathrm{Hb}$ affinity for $\mathrm{O}_{2}$. When the flows are mixed, the processes proceed without the participation of membranes, with the creation of new levels of $\mathrm{pO}_{2}$ and $\mathrm{SO}_{2}$. Blood with low $\mathrm{SO}_{2}$ carries out forced dissociation of $\mathrm{HbO}_{2}$, as in the transmembrane interaction of $\mathrm{Hb}$ and $\mathrm{Mb}$ in the heart, as well as in arterial blood and VR blood in the counterflow system of the kidney. In other words, the described mechanism allows us to consider the venous system of the organs represented as an internal oxygenator, ensuring cooperative multi-organ regulation of homeostasis as a whole.

The proposed integral tests reveal qualitative differences in the functioning of the organ-blood systems, which are not detected by the generally accepted tests:

a) In the myocardium block, when Ao blood periodically enters the exchange zone, where the minimum levels of $\mathrm{pO}_{2}$, $\mathrm{HbO}_{2}(\%)$, SC PS are created, Gradient DP is maintained positive, and maximum gas gradients are created, including Gas functional.

b) In the microcirculatory bed of the kidney block (with participation of countercurrent metabolism), the maximum (venous) levels of $\mathrm{pO}_{2}, \mathrm{HbO}_{2}(\%)$, VR PS and the minimal Gas gradients, including Gas functional, are created during 1 cardiocycle. 
Table 1. Integrated gas indicators at various points of the human body

\begin{tabular}{|c|c|c|c|c|c|c|c|c|c|}
\hline \multicolumn{2}{|c|}{ Variable } & PS Ao & PS PT & PS VJI & PS VH & \begin{tabular}{|l|l} 
PS SC & 1 \\
\end{tabular} & \begin{tabular}{|l|} 
PS VR \\
\end{tabular} & GD & GDP \\
\hline \multirow{11}{*}{ Ao } & $\mathrm{K}$ pl & & & & + & & & & \\
\hline & $\mathrm{K}$ er & + & & + & & & & & \\
\hline & $\mathrm{Na} \mathrm{pl}$ & - & + & - & + & & & & \\
\hline & $\mathrm{Na}$ er & - & - & . & + & & & & \\
\hline & $\mathrm{pH}$ & - & - & - & + & & & & \\
\hline & $\mathrm{pCO}_{2}$ & 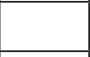 & + & + & + & & & & \\
\hline & SB & - & - & - & - & & & & \\
\hline & $\mathrm{pO}_{2}$ & + & + & + & + & + & + & & \\
\hline & $\mathrm{HbO}_{2}$ & + & + & + & & & & & \\
\hline & $\mathrm{Hb}$ & & & & & & & & \\
\hline & $\mathrm{pS} \mathrm{Ao}$ & 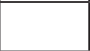 & + & + & & & & & \\
\hline \multirow{11}{*}{ PT } & $\mathrm{K} \mathrm{pl}$ & + & . & & . & & & & \\
\hline & $\mathrm{K}$ er & & + & & + & & & & \\
\hline & $\mathrm{Na} \mathrm{pl}$ & + & & & & & & & \\
\hline & $\mathrm{Na}$ er & - & 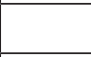 & + & + & & & & \\
\hline & $\mathrm{pH}$ & 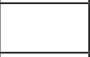 & + & & + & & & & \\
\hline & $\mathrm{pCO}_{2}$ & 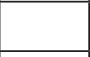 & + & & + & & & & \\
\hline & SB & - & + & & & & & & \\
\hline & $\mathrm{pO}_{2}$ & + & + & + & + & & & & \\
\hline & $\mathrm{HbO}_{2}$ & + & + & + & - & & & & \\
\hline & $\mathrm{Hb}$ & . & & & & & & & \\
\hline & $\mathrm{pS}$ PT & + & 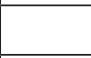 & + & + & & & & \\
\hline \multirow{11}{*}{ VJI } & $\mathrm{K} \mathrm{pl}$ & & + & + & & & & & \\
\hline & K er & - & - & - & + & & & & \\
\hline & $\mathrm{Na} \mathrm{pl}$ & - & - & - & & & & & \\
\hline & $\mathrm{Na}$ er & & - & 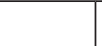 & - & & & & \\
\hline & $\mathrm{pH}$ & - & & - & & & & & \\
\hline & $\mathrm{pCO}_{2}$ & & + & + & + & & & & \\
\hline & SB & - & - & - & - & & & & \\
\hline & $\mathrm{pO}_{2}$ & + & + & + & + & & & & \\
\hline & $\mathrm{HbO}_{2}$ & + & & + & - & & & & \\
\hline & $\mathrm{Hb}$ & & & & & & & & \\
\hline & PS VJI & + & + & & - & & & & \\
\hline
\end{tabular}

Table 1. (Continued)

\begin{tabular}{|c|c|c|c|c|c|c|c|c|c|}
\hline \multicolumn{2}{|c|}{ Variable } & PS AO & PS PT & PS VJI & PS VH & PS SC & PS VR & GD & GDP \\
\hline \multirow{11}{*}{ VH } & $\mathrm{K}$ pl & + & & & + & & & & \\
\hline & $\mathrm{K}$ er & - & + & - & + & & & & \\
\hline & $\mathrm{Na} p l$ & - & - & - & & & & & \\
\hline & $\mathrm{Na}$ er & & - & & - & & & & \\
\hline & $\mathrm{pH}$ & - & & - & & & & & \\
\hline & $\mathrm{pCO}_{2}$ & . & - & + & + & & & & \\
\hline & SB & - & & & & & & & \\
\hline & $\mathrm{pO}_{2}$ & + & + & + & + & & & & \\
\hline & $\mathrm{HbO}_{2}$ & + & & + & - & & & & \\
\hline & $\mathrm{Hb}$ & & . & & & & & & \\
\hline & pS VH & & + & - & & & & & \\
\hline \multirow{3}{*}{$\mathrm{SC}$} & $\mathrm{pCO}_{2}$ & & & & & + & + & & \\
\hline & $\mathrm{pO}_{2}$ & & & & & & & & \\
\hline & $\mathrm{Hb}$ & & & & & & & & \\
\hline \multirow{3}{*}{ VR } & $\mathrm{pO}_{2}$ & & & 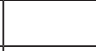 & & + & & & \\
\hline & $\mathrm{pCO}_{2}$ & & & 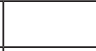 & & & + & & \\
\hline & $\mathrm{Hb}$ & & & & & & & & \\
\hline \multirow{4}{*}{ Ao } & $\mathrm{sp}$ & - & + & - & & $x$ & $x$ & - & - \\
\hline & $d p$ & - & - & - & & $x$ & $x$ & - & \\
\hline & $\mathrm{pp}$ & . & + & . & & $x$ & $x$ & & \\
\hline & $\mathrm{mp}$ & - & - & - & & $x$ & $x$ & - & \\
\hline \multirow{4}{*}{ PT } & $\mathrm{sp}$ & - & - & - & & $x$ & $x$ & - & - \\
\hline & $\mathrm{dp}$ & - & - & - & + & $x$ & $x$ & & - \\
\hline & $\mathrm{pp}$ & - & - & - & & $x$ & $x$ & - & - \\
\hline & $\mathrm{mp}$ & - & - & - & 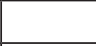 & $x$ & $x$ & - & - \\
\hline \multirow{4}{*}{ VJI } & $\mathrm{sp}$ & - & - & - & - & $x$ & $x$ & - & \\
\hline & $\mathrm{dp}$ & - & - & - & - & $x$ & $x$ & & \\
\hline & $\mathrm{pp}$ & - & - & - & - & $x$ & $x$ & & - \\
\hline & $\mathrm{mp}$ & - & - & - & - & $x$ & $x$ & & \\
\hline \multirow{4}{*}{ VH } & $\mathrm{sp}$ & & - & & - & $x$ & $x$ & - & \\
\hline & $\mathrm{dp}$ & - & - & - & 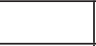 & $x$ & $x$ & & - \\
\hline & pp & + & - & + & - & $x$ & $x$ & - & + \\
\hline & $\mathrm{mp}$ & - & - & & - & $x$ & $x$ & - & \\
\hline PS PT & & + & & + & + & $x$ & $x$ & & \\
\hline PS VH & & & + & - & & $x$ & $x$ & & \\
\hline GD & & + & + & & & & & $x$ & $x$ \\
\hline GDP & & + & + & & & & & $x$ & $x$ \\
\hline
\end{tabular}

Table 2.

Blood gas parameters in the points studied

\begin{tabular}{|l|c|c|c|c|c|c|}
\hline \multicolumn{1}{|c|}{ Variable } & $\mathrm{pO}_{2}$ & $\mathrm{PCO}_{2}$ & $\mathrm{PS}$ & $\mathrm{pH}$ & $\mathrm{SO}_{2}$ & $\mathrm{Pmed}$ \\
\hline $\mathrm{SC}$ & $23.77 \pm 0.30$ & $47.50 \pm 0.34$ & $71.3 \pm 0.6$ & $7.345 \pm 0.005$ & $38.02 \pm 0.70$ & $5.3 \pm 0.4$ \\
\hline $\mathrm{TP}$ & $42.96 \pm 0.40$ & $41.86 \pm 0.30$ & $84.80 \pm 0.50$ & $7.372 \pm 0.003$ & $76.80 \pm 0.42$ & $14.0 \pm 0.2$ \\
\hline $\mathrm{Ao}$ & $91.70 \pm 0.54$ & $36.62 \pm 0.21$ & $128.3 \pm 0.6$ & $7.396 \pm 0.003$ & $96.74 \pm 0.07$ & $86.5 \pm 1.7$ \\
\hline $\mathrm{VJ}$ & $37.95 \pm 0.57$ & $47.95 \pm 0.24$ & $84.89 \pm 0.54$ & $7.353 \pm 0.003$ & $68.21 \pm 0.74$ & $6.7 \pm 1.3$ \\
\hline $\mathrm{VH}$ & $43.63 \pm 0.49$ & $44.88 \pm 0.34$ & $88.51 \pm 0.54$ & $7.360 \pm 0.004$ & $76.76 \pm 0.62$ & $8.38 \pm 1.38$ \\
\hline $\mathrm{VR}$ & $59.4 \pm 1.20$ & $41.35 \pm 0.24$ & $100.7 \pm 0.80$ & $7.375 \pm 0.003$ & $87.75 \pm 0.46$ & $8.97+1.74$ \\
\hline $\mathrm{D}($ Ao $-\mathrm{V})$ & $\mathrm{DpO}_{2}$ & $\mathrm{DPCO}_{2}$ & $\mathrm{DPS}$ & $\mathrm{DpH}$ & $\mathrm{DSO}_{2}$ & \\
\hline $\mathrm{D}($ Ao $-\mathrm{SC})$ & $67.93 \pm 0.43$ & $-10.9 \pm 0.26$ & $57.00 \pm 0.42$ & $0.051 \pm 0.002$ & $58.70 \pm 0.73$ & \\
\hline $\mathrm{D}($ Ao $-\mathrm{TP})$ & $43.77 \pm 0.47$ & $-4.31 \pm 0.21$ & $39.46 \pm 0.45$ & $0.023 \pm 0.001$ & $19.48 \pm 0.40$ & \\
\hline $\mathrm{D}($ Ao $-\mathrm{VJI})$ & $46.72 \pm 1.86$ & $-8.79 \pm 0.97$ & $37.93 \pm 2.27$ & $0.030 \pm 0.006$ & $24.35 \pm 2.53$ & \\
\hline $\mathrm{D}($ Ao $-\mathrm{VH})$ & $46.82 \pm 0.55$ & $-5.51 \pm 0.25$ & $41.31 \pm 0.60$ & $0.025 \pm 0.002$ & $20.00 \pm 0.60$ & \\
\hline $\mathrm{D}$ (Ao - VR) & $29.40 \pm 0.54$ & $-2.88 \pm 0.16$ & $26.51 \pm 0.50$ & $0.013 \pm 0.001$ & $8.76 \pm 0.40$ & \\
\hline
\end{tabular}


In this case, VR PS $>\mathrm{Ao}_{\mathrm{pO}}$; as a result, Gradient DP is negative and multidirectional with respect to the remaining gradients of the gas parameters in the heart-lung block, brain block and liver block with minimization of deviations from zero (destruction of differences between $\mathrm{Ao}_{\mathrm{pO}}$ and the venous PS), where the common mechanism is the formation (after mixing) of flows with different levels of $\mathrm{pO}_{2}$ and $\mathrm{HbO}_{2}(\%)$ in a zone of values between the maximum level of Gradient D (A-SC) created in the myocardium block and the minimum level of Gradient D (A-VR) created in the kidney block. ${ }^{(4,16-24,34-37)}$ Normally, the possible deviations in Gradient DP of organs do not reach DP value in the myocardium block (with the + sign) or in the kidney block (with the sign -).

We consider the venous system as a special organ which, in addition to other functions, participates in the overall metabolism by mixing blood flows with differences in $\mathrm{pO}_{2}, \mathrm{pCO}_{2}$ and $\mathrm{HbO}_{2} \%$, having the function of maintaining the gradients by integral gas parameters between different exchange zones. An important condition for the norm of gas exchange as a whole is the minimization of deviations from the average PS value. ${ }^{(26)}$ Minimization of differences between organs by PS occurs while maintaining the differences between them, according to $\mathrm{pO}_{2}, \mathrm{pCO}_{2}, \mathrm{pH}, \mathrm{SO}_{2}$ and their ratios in the arterial and venous systems, being a reflection of polyorganic interactions.

Maintaining multidirectional deviations in Gradient DP from the zero in the kidney block and myocardium block indicates their conjugated functioning, the derivatives of which are gas-hemodynamic complexes that limit the amplitude of oscillations of the gas parameters in the brain, liver, and heartlung blocks.

The stability of the homeostasis of the liquid medium of the body in interaction with the external gaseous environment is maintained through the interrelation of metabolic processes in the studied blocks, in which our tests, relatively independent from factors affecting $\mathrm{O}_{2}$ transport $(\mathrm{Hb}$, stroke and minute heart volumes), allow us not only to detect changes, but also to create mechanisms influencing organ functioning, both in the normal and pathology states.

We believe that PS in the liquid media of the human body that depends on the combined processes (tissue, plasma, erythrocyte, external respiration, hemodynamics, etc.), as a derivative from the total pressure of gases in gas media (alveolar air, atmospheric air), is an evolutionary-deterministic basis for the formation of all types of pressure, including hemodynamic pressure. Tests for PS are an integral part of the analysis of a single cooperative system of the regulation of metabolism and other functions of the human body by pressure (arterial, venous, intracardiac, tissue, liquor, oncoosmotic, amniotic, etc.).

\section{Conclusion}

Summary gas pressure (PS) is a mechanism to maintain the stability of intrasystemic metabolic processes and gas homeostasis as a whole. The processes forming PS limit the amplitude of the PS deviation under changing the parameters of the constituent components $\left(\mathrm{pO}_{2}\right.$ and $\left.\mathrm{pCO}_{2}\right)$ due to acts of "mutual replacement" between them, as well as the influence of integral gas complexes under shifts in $\mathrm{pO}_{2}, \mathrm{pCO}_{2}, \mathrm{~A}-\mathrm{V} \mathrm{SO}_{2}$. Processes that minimize the fluctuations in the sum of gases, in contrast to the volume tests $\left(\mathrm{O}_{2} \mathrm{v} \%, \mathrm{CO}_{2} \mathrm{v} \%, \mathrm{HbO}_{2} \%\right)$, are relatively independent from factors affecting the $\mathrm{O}_{2}$ transport $\left(\mathrm{Hb}\right.$, stroke and minute heart volumes, $\mathrm{SO}_{2}$ dissociation regulation systems). This makes it possible to consider them as significant factors for stabilizing the homeostatic control of the gas-hemodynamic environment of the human body. GDP, as a measure of the adequacy of the combined changes in arterial $\mathrm{pO}_{2}$ and venous PS, is relevant for multi-organ monitoring of metabolic processes and inter-system relations in dynamics: norm - compensation - subcompensation - decompensation. Unlike the generally accepted tests that record quantitative differences between the points studied, the integral gas tests allow us to identify vectors and mechanisms of adaptive changes in gas homeostasis, to perform a qualitative comparison of the functioning of the studied organs by gas-dynamic tests in the norm and in pathology.

\section{Competing interests}

The authors declare that they have no competing interests.

\section{References}

1. Kruglov AG, Utkin VN, Vasilyev AY, Sherman V. Human Homeostatic Control in Norm. International Journal of Biomedicine. 2016;6(3):184-9.

2. Gebel GYa, Kruglov AG, Utkin VN, Golostenova LM, Dasaev AN, Ignatov NG. [The total gas pressure $\left(\mathrm{PS}=\mathrm{pO}_{2}+\mathrm{pCO}_{2}\right)$ in the blood of the outflow vessels from the human ventricular block in norm]. Proceeding of the 2nd Russian Congress on Pathophysiology. M., 2000:64. [Abstract in Russian].

3. Gebel GYa, Golostenova LM, Kruglov AG, Dasaev AN, Utkin VN, et al. Hemodynamics and gas characteristics in normal human heart vessels-coronary sinus and aorta. Proceeding of the 9th European Congress on Anaesthesiology. Jerusalem, 1994:476.

4. Gebel GYa, Kruglov AG, Utkin VN, Golostenova LM, Dasaev AN, Ignatov NG, et al. Summary gas pressure $\left(\mathrm{pO}_{2}+\mathrm{pCO}_{2}\right)$ in blood of sinus coronarius, arteria pulmonalis and the aorta in healthy adult humans. Proceedings of the $10 \mathrm{t}^{\mathrm{h}}$ International Congress on Cardiovascular Pharmacotherapy. Kioto, 2001;15(1):394

5. Gebel GYa, Kruglov AG, Utkin VN, Golostenova LM, Dasaev AN, Ignatov NG, Suvorov SG. [The total pressure of gases in the blood of the coronary sinus of the heart, pulmonary artery and aorta in humans in norm]. Proceedings of the 5th All-Russian Congress of Cardiovascular Surgeons. Novosibirsk. 1999: 217.[Abstract in Russian].

6. Gebel GYa, Degtyarev VA, Dasaev AN, Utkin VN, Kruglov AG, Gudenko V. [The role of tests on the total pressure of gases $\left(\mathrm{pO}_{2}+\mathrm{pCO}_{2}\right)$ in blood plasma in the study of gas homeostasis in the human body]. Kosmicheskaia Biologiia I Aviakosmicheskaia Meditsina. 1987;21(4):31-41.[Article in Russian].

7. Gebel GYa, Degtyarev VA, Dasaev AN, Utkin VN, Kruglov AG, et al. [On the criteria for the regulation of gas exchange in the human brain]. Proceedings of the 14th scientific Gagarin readings on Aviation and Cosmonautics. M., 1984:80-81. 
8. Gebel GYa, Golostenova LM, Kruglov AG, Utkin VN, Bagdatyev VE, Dasaev AN. [The state of gas parameters in the venous system of the human body in norm]. Proceedings of the 10th Conference of Space Biology and Aerospace Medicine. M., 1994:57-58. [Abstract in Russian].

9. Gebel GYa, Golostenova LM, Kruglov AG, Dasaev AN, Utkin VN, Bagdatyev VE, et al. The gas exchange in normal human fetus. Proceedings of the 9th European Congress on Anaesthesiology, Jerusalem, 1994:218.

10. Gebel GYa, Kruglov AG, Utkin VN, et al. [The total gas pressure $\left(\mathrm{pO}_{2}+\mathrm{pCO}_{2}\right)$ in assessing the gas exchange of kidneys in humans in norm]. Proceedings of the 6th All-Russian Congress of anesthesiologists and resuscitators. M., 1998; №184:88. [Abstract in Russian].

11. Gebel GYa, Kruglov AG, GolostenovaLM, Dasaev AN, Utkin VN, Bagdatyev VE, et al. Summary gas pressure $\left(\mathrm{pO}_{2}+\mathrm{pCO}_{2}\right)$ tests in normal fetal gas exchange evaluation at the stage of placental circulation. Proceedings of the 9 th Int Hypoxia Symp at Lake Louise, Canada, 1995;321:38.

12. Gebel GYa, Kruglov AG, Utkin VN, Golostenova LM, Dasaev AN, Ignatov NG, Suvorov SG. [The total gas pressure $\left(\mathrm{pO}_{2}+\mathrm{pCO}_{2}\right)$ in the aorta and hepatic vein in persons of the practical norm (for monitoring heart operations)]. Proceedings of the 5th All-Russian Congress on Cardiovascular Surgery. M.,1999:216-217. [Abstract in Russian].

13. Gebel GYa, Kruglov AG, Golostenova LM, Dasaev AN, Utkin VN, Bagdatyev VE, et al. The function of the «ventricle block» in human heart. Intensive care for young. Acta Anaesthesiologica Scandinavica, 1996;40 Supl 109: S116. 14. Gebel GYa, Kruglov AG, Utkin VN, Dasaev AN, Golostenova LM, Bagdatyev VE, et al. [About the function of the ventricular block of the human heart in norm]. Proceedings of the Conference "Man in Aviation and Cosmonautics." M., 1995;101-103. [Article in Russian].

15. Gebel GYa, Kruglov AG, Utkin VN, Golostenova LM, Dasaev AN, Ignatov NG, Suvorov SG. [Integral indicators in lung function evaluation in norm]. Proceedings of All-Russia scientific and practical conference "Problems of therapeutic and surgical pulmonology." St. Petersburg, 1997:49-52. [Article in Russian].

16. Gebel GYa, Dasaev AN, Kruglov AG, Utkin VN, Bagdatyev $\mathrm{VE}$, Ignatov NG, et al. [On the role of the coronary sinus of the human heart in the regulation of a number of functions]. Proceedings of the 4th Congress of Anaesthesiologists and Reanimatologists. M., 1994:141-143.[Article in Russia].

17. Gebel GYa, Dasaev AN, Belichenko IA, Kruglov AG, Gudenko VV, Utkin VN. [Intracranial venous pressure in the norm and arterial hypertension]. Proceedings of the 7th Union Conference on Space and aerospace medicine. Kaluga,1982:184. [Abstract in Russian].

18. Gebel GYa, Kruglov AG, Utkin VN, Golostenova LM, Dasaev AN, Ignatov NG, et al. [Tests on the total gas pressure in the evaluation of gas exchange of a human fetus in norm (Monitoring of the fetus during delivery)]. Vestnik Intensivnoi Terapii. 1996;2:26. [Abstract in Russian].

19. Gebel GYa, Degtyarov VA, Dasaev AN, Utkin VN, Lilloson AA, Kruglov AG. [About Criteria of Human Circulatory Hypoxia]. Proceedings of the International Soc Pathophysiology. M.,1991:318. [Abstract in Russian].

20. Gebel GYa, Golostenova LM, Dasaev AN, Kruglov AG, Utkin VN. Summable gas pressure $\left(\mathrm{O}_{2}+\mathrm{CO}_{2}\right)$ in human pulmonary artery blood. Inten Care Med. 1995; 20:140.

21. Gebel GYa, Kruglov AG, Utkin VN, Golostenova LM,
Dasaev AN, Bagdatyev VE, et al. [Cerebral gas exchange in patients with arterial hypertension]. Cardiovascular Surgery. 1995:33. [Abstract in Russian].

22. Gebel GYa, Kruglov AG, Utkin VN, Golostenova LM, Dasaev AN, Ignatov NG, Suvorov SG. The assessment of the functional "ventricular block" in health individuals. Proceedings of the 3th World congress of pediatric cardiology and cardiac surgery. Canada, 2001:439.

23. Gebel GYa, Kruglov AG, Utkin VN, Golostenova LM, Dasaev AN, Ignatov NG, Suvorov SG. Summary gas pressure $\left(\mathrm{pO}_{2}+\mathrm{pCO}_{2}\right)$ tests in the evaluation gas exchange in normal human. Proceedings of the 10th Intern Hypoxia Symp. Canada;1997:310.

24. Gebel GYa, Kruglov AG, Utkin VN, Golostenova LM, Dasaev AN, Ignatov NG, Suvorov SG. [Venous hemodynamics in human liver]. Russian J Gastroenterol Hepatol Coloproctol. 1997; 5(Suppl 4):139-41. [Article in Russian].

25. Gebel GYa, Kruglov AG, Golostenova LM, Dasaev AN, Utkin VN, Bagdatyev VE, et al. Summary gas pressure $\left(\mathrm{pO}_{2}+\mathrm{pCO}_{2}\right)$ in blood plasma during pulmonary gas exchange in normal adults. Proceedings of the 9th Intern Symp on Hypoxia. Canada, 1995:27.

26. Gebel GYa, Kruglov AG, Golostenova LM, Utkin VN, Dasaev AN, Bagdatyev VE, et al. [The total gas pressure in the evaluation of brain gas exchange in the human body in norm]. Vestnik Intensivnoi Terapii. 1996;2:25-26. [Abstract in Russian].

27. Gebel GYa, Utkin VN,Dasaev AN,Smirnov EP, Kruglov AG. [On gas exchange of the brain, heart, kidneys in a human]. Collection of scientific articles "Clinical aspects of the posthypoxic encephalopathy. Rehabilitation of comatose and postcomatose patients. M. 15-17 December, 1992: 32-38. [Article in Russian].

28. Gebel GYa, Kruglov AG, Utkin VN, Golostenova LM, Dasaev AN, Bagdatyev VE, et al. [To analyze of the activity of the ventricles of the heart in humans is norm]. Collection of scientific articles "Resuscitation at the turn of the XXI century.” M., 1996: 89-91. [Article in Russian].

29. Gebela GY, Kruglov AG, Utkin VN, Golosnenova LM, Dasaev AN, Ignatov NG, Suvorov SG. Summary gas pressure $\left(\mathrm{pO}_{2}+\mathrm{pCO}_{2}\right)$ in aorta and pulmonary artery blood in normal human. Proceedings of the 7th World Cong. Int Soc Cardiothor Surg. Dusseldorf, Germany; 1997:348.

30. Gebel GYa, Kruglov AG, Golostenova LM, Dasaev AN, Utkin VN, Bagdatjev VE, et al. About function of the "ventricular block" in human heart. Proceedings of the 2nd World congress on pediatric intensive care, Rotterdam,1996; 22(Suppl 2):163.

31. Gebel GYa, Kruglov AG, Utkin VN, Golostenova LM, Dasaev AN, Ignatov NG, Suvorov SG. Summary gas pressure $\left(\mathrm{PO}_{2}+\mathrm{PCO}_{2}\right)$ in aorta and pulmonary artery blood in "normal" human. Anesthesiol Intensiv Med Notfaltmed Schmerztheerapie. Gamburg, 1997 (Suppl.32):173.

32. Gebel GYa, Kruglov AG, Utkin VN, Golostenova LM, Dasaev AN, Bagdatyev VE, et al. [The total pressure of gases in the blood plasma in humans in norm]. Proceedings of the First Moscow International Congress of Surgeons. M.,1995: 149-151. [Abstract in Russian].

33. Gebel GYa, GolostenovaLM, Dasaev AN, Utkin VN, Kruglov AG, et al. Total gas pressure in normal human plasma. Proceedings of the 7 th European Congress on Intensive Medicine. Insbruck, 1994;20:104.

34. Gebel GYa, Kruglov AG, Utkin VN, Golostenova 
LM, Dasaev AN, Bagdatyev VE, et al. [The total gas pressure $\left(\mathrm{pO}_{2}+\mathrm{pCO}_{2}\right)$ in the blood plasma in assessing the gas exchange in organs of the splanchnic pool in humans in norm]. Proceedings of the First Russian Congress of Pathophysiologists. M., 1996:118.[Abstract in Russian].

35. Gebel GYa, Golostenova LM, Dasaev AN, Utkin VN, Kruglov AG, Bagdatyev VE, et al. [Blood composition of the coronary sinus in healthy people]. Proceedings of the 7 th Russian Symposium "Ecological and physiological problems of adaptation." Moscow, 26-28 April, 1994: 59-60.[Article in Russian].
36. Gebel GY, Kruglov AG, Utkin VN, Golostenova LM, Dasaev AN, Bagdatyev VE, et al. [The gas exchange in the human brain in norm and arterial hypertension]. Proceedings of the Conference "Man in aviation and astronautics. Past, Present, Future. Aviatsionnaia i Kosmicheskaia Meditsina Psikhologiia i Ergonomika. 1995: 98-101. [Article in Russian]. 37. Gebel GY, Kruglov AG, Utkin VN, Golostenova LM, Dasaev AN, Bagdatyev VE, et al. [The total gas pressure $\left(\mathrm{pO}_{2}+\mathrm{pCO}_{2}\right)$ in blood plasma in the evaluation of gas exchange in arterial hypertension]. Proceedings of the First Congress of Association of Cardiologists of CIS countries. M.,1997:158. 